\title{
Increased absolute calcium binding to albumin in hypoalbuminaemia
}

\author{
ANATOLE BESARAB, JOSE F CARO \\ From the Departments of Medicine and Physiology, Jefferson Medical College of Thomas Jefferson \\ University, Philadelphia, USA
}

SUMMARY The amount of calcium bound to protein was measured in 30 patients with differing diseases and varying degrees of hypoalbuminaemia. Total serum calcium increased directly with both serum albumin and ultrafilterable calcium concentrations. The estimated amount of calcium bound per gram of albumin varied inversely with the albumin concentration, decreasing from 2.0 to $1.0 \mathrm{mg}$ calcium/g albumin as albumin concentration increased from 1.7 to $3.1 \mathrm{~g} / \mathrm{dl}$. Circulating parathyroid hormone (PTH) concentrations varied inversely with measured ultrafilterable calcium concentrations. The frequency of raised PTH concentrations decreased as serum albumin increased. Use of a conventional correction factor for albumin binding $(0.88 \mathrm{mg}$ calcium bound per gram of albumin) to calculate corrected total calcium led to major errors in estimating ultrafilterable calcium in these patients. The PTH concentrations in turn correlated with the degree of deviation between estimated and measured ultrafilterable calcium concentrations. Ionised calcium was low in seven of ten additional hypoalbuminaemic patients studied whereas correction of total calcium for albumin indicated normocalcaemia in all. Thus correction of total calcium in patients with hypoalbuminaemi by formulae which use a fixed binding ratio of calcium to albumin may give an erroneous impression of normocalcaemia. The increase in calcium binding ratio during hypoalbuminaemia needs to be considered during assessment of calcium status in these patients.

The distribution of total serum calcium in three separate forms has been known for over four decades. ${ }^{1}$ Total serum calcium consists of ionised $\left(\mathrm{Ca}^{2+}\right)$, chelated $(\mathrm{Ca})$, and protein bound $(\mathrm{CaPr})$ moieties with the ionised moiety being physiologically important for a variety of neuromuscular and general cellular functions. Changes in chelated and protein bound calcium appear to be important only to the extent that they influence ionised calcium. Since alterations in serum proteins occur under a variety of physiological and pathophysiological conditions, ${ }^{2-5}$ a variety of formulae have been developed to correct total calcium for the effect of changes in protein concentrations. ${ }^{4-9} \mathrm{~A}$ recent detailed study by Ladenson et al ${ }^{10}$ found that none of the published formulations adequately predicted the ionised calcium status of a given individual.

Studies in various disease states do suggest that the pattern of distribution of calcium among the three factions may vary ${ }^{211-13}$ The complexity of these changes between free calcium and total calcium

Accepted for publication 18 March 1981 is such that no useful equation is available with which to estimate $\mathrm{Ca}^{2+}$ from total calcium when managing a particular patient. In clinical states associated with hypoalbuminaemia, patients may manifest symptoms of hypocalcaemia over a wide range of serum calcium concentrations. The possible presence of hypocalcaemia is usually assessed by correcting total serum calcium for hypoalbuminaemia using a fixed calcium-albumin binding value of 0.7 to $1.0 \mathrm{mg}$ calcium $/ \mathrm{g}$ albumin. ${ }^{14}$ The amount of calcium bound per gram of albumin is assumed to 윽 be independent of the absolute concentration of $\rightarrow$ albumin. The careful studies of McLean and Hastings, ${ }^{1}$ however, indicated that the total calcium $\mathrm{N}$ could only be interpreted by considering the relative $O$ amounts of ionised calcium and protein present. Our $\mathcal{N}$ previous observations ${ }^{15}$ on calcium binding to $\underset{\omega}{N}$ albumin in vitro suggested that the affinity of calcium binding and the molar binding ratio were 0 strongly influenced by the relative concentrations of $\frac{\infty}{\Phi}$ albumin and calcium present suggesting to us that $\stackrel{\mathcal{D}}{+}$ at low albumin concentrations use of a fixed ratio 0 for mg of calcium bound per gram of albumin might 
lead to erroneous estimation of the total calcium actually present and mask the presence of decreased $\mathrm{Ca}^{2+}$. We therefore studied patients with hypoalbuminaemia to ascertain two aspects: first, whether the binding of calcium to proteins in vivo was influenced by the absolute serum albumin concentration; second, whether we could develop a formulation that would permit more accurate estimation of the $\mathrm{Ca}^{2+}$ in hypoalbuminaemic patients.

\section{Patients and methods}

\section{PATIENT SELECTION}

One patient (index patient) was studied while sequentially hypercalcaemic, hypocalcaemic and normocalcaemic. Results in this patient led to studies in other patients. Potential study patients were identified by screening the clinical chemistry computer printout sheets for the presence of hypoalbuminaemia $(<3.5 \mathrm{~g} / \mathrm{dl})$ and hypocalcaemia $(<9.2 \mathrm{mg} / \mathrm{dl})$.

\section{PATIENT CHARACTERISTICS}

The next 30 patients studied had a variety of disease processes: 15 with cancer, 6 with cirrhosis, 3 with marked malnutrition due to debilitating diseases (congestive heart failure, stroke, inanition), 2 with moderate renal failure, 1 with nephrotic syndrome, 2 with inflammatory disease (rheumatoid arthritis and ulcerative colitis) while on steroid treatment, and one each with myelofibrosis and complicated toxaemia of pregnancy. Among the cancer patients carcinoma of the colon was most common (6 patients), other primary sites included rectum and breast ( 2 patients each), pancreas, liver, lung, vagina and multiple myeloma. Metastases were invariably present and these patients were moderately to severely decompensated; one had alcoholic hepatitis.

In the above patients, ionised calcium was not measured since the method was not available at the time the studies were performed. For this reason we studied an additional 10 patients in whom ionised calcium was measured. Four patients had nephrotic syndrome, 3 had cancer, and 3 had liver disease.

\section{ANALYTICAL METHODS}

Blood was collected without venous stasis into vacutainers, centrifuged, and the serum anaerobically removed. Ultrafilterable calcium was determined by pressure filtration at $37^{\circ} \mathrm{C}$ through Amicon CR 25 membranes with total ultrafiltration limited to less than $6 \%$ of the plasma volume. After discarding the initial $0.5 \mathrm{ml}$ formed (dead space fluid), two consecutive $50 \mu$ l ultrafiltrate samples were collected from an initial total plasma volume of 12 to $15 \mathrm{ml}$. The actual ultrafiltrate volume collected for analysis thus represented less than $1 \%$ of the retentate volume. On some samples, plasma ionised calcium was measured before and after ultrafiltration. Otherwise the serum retentate was processed directly to measure total calcium, total protein, and albumin concentrations.

Albumin concentrations were measured by electrophoresis. The coefficient of variation for albumin by electrophoreses was 5\%. Total and ultrafilterable calcium was measured by atomic absorption spectrophotometry (Perkin Elmer, Model 353) with a coefficient of variation of $2 \cdot 1 \%$ plasma (pre and post ultrafiltration). Ionised calcium was measured with an Orion SS 20 system having a coefficient of variation of $2.6 \%$. Replicate determinations of total protein (TP) were within 0.05 to $0.2 \mathrm{~g} / \mathrm{dl}$ (Biuret). Normal parathyroid hormone concentrations (carboxy-terminal immunoassay) were less than 400 picograms $/ \mathrm{ml}$.

\section{CALCULATIONS AND STATISTICS}

To calculate the amount of calcium bound per gram of albumin, it is necessary to know what fraction of protein bound calcium is bound by other proteins. Non-albumin proteins in normal sera account for approximately $10-25 \%$ of the protein bound calcium. ${ }^{1617}$ Regression analyses were performed using albumin, and total protein concentrations as the independent variables. Based on the regression correlation coefficients obtained (vida infra), it was not possible to develop a correction factor for nonalbumin protein bound calcium. We therefore equated albumin bound calcium with total protein bound albumin realising that an error as large as $25 \%$ might be present in some patients. Linear regressions were done by the method of least squares. Results are expressed as mean \pm SD.

\section{Results}

\section{CALCIUM PROTEIN RELATIONS}

The results from the index patient with multiple myeloma are shown in Table 1. This patient was studied at three different levels of Сат. Over the study period, her serum albumin varied from 3.4 to $4 \cdot 1 \mathrm{~g} / \mathrm{dl}$. Total and bound calcium varied directly

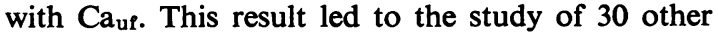
patients with varying levels of serum albumin and total calcium concentrations. The results are summarised in Table 2.

The relation between total calcium and serum albumin in these patients is shown in Fig. 1. There was a significant direct relation between $\mathrm{Ca}_{\mathbf{T}}$ and serum albumin concentration $(r=0.70, p<0.001)$. 
Table 1 Distribution of serum calcium in a patient with multiple myeloma

\begin{tabular}{|c|c|c|c|c|c|c|}
\hline Hospital day & $\begin{array}{l}C a_{T} \\
(m g / d l)\end{array}$ & $\begin{array}{l}C a_{u f} \\
(m g / d l)\end{array}$ & $\begin{array}{l}C a P r \\
(m g / d l)\end{array}$ & $\begin{array}{l}A l b \\
(g / d l)\end{array}$ & $\begin{array}{l}T P \\
(g / d l)\end{array}$ & $\frac{C a_{u f}}{C a_{T}} \times 100$ \\
\hline $\begin{array}{r}2 \\
16 \\
29\end{array}$ & $\begin{array}{r}18.8 \\
6.0 \\
10 \cdot 2\end{array}$ & $\begin{array}{r}10.3 \\
3.0 \\
5 \cdot 3\end{array}$ & $\begin{array}{l}8.5 \\
3.0 \\
4.9\end{array}$ & $\begin{array}{l}4 \cdot 1 \\
3 \cdot 4 \\
3 \cdot 5\end{array}$ & $\begin{array}{l}8 \cdot 8 \\
7 \cdot 6 \\
7 \cdot 4\end{array}$ & $\begin{array}{l}55 \\
50 \\
52\end{array}$ \\
\hline
\end{tabular}

Table 2 Calcium binding to protein in 30 patients

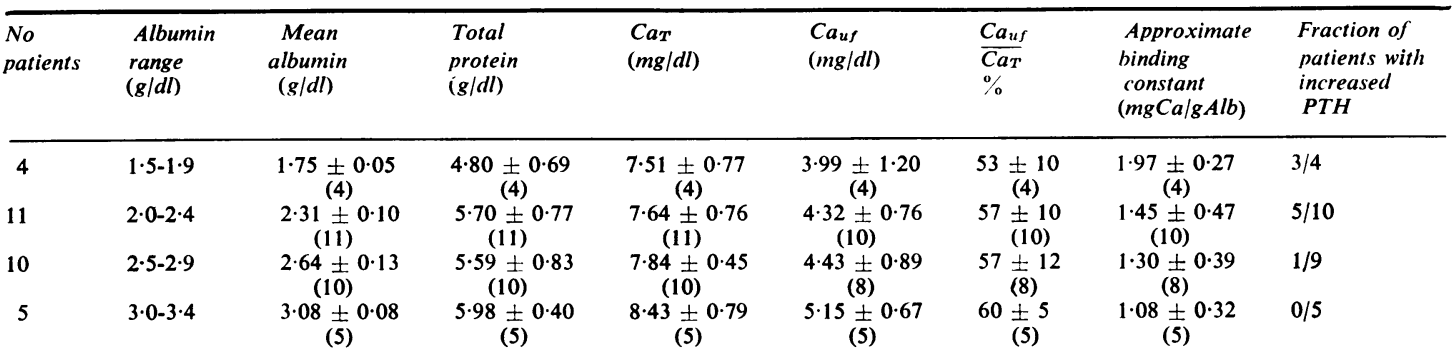

Numbers in parentheses reflect number of measurements. Results are mean $\pm S D$.

Although $\mathrm{Ca}_{\mathrm{T}}$ also correlated with total protein $\left(\mathrm{Ca}_{\mathrm{T}}=5.19+0.48 \mathrm{TP}\right)$, the correlation coefficient was even lower at 0.52 . This decrease in the degree of correlation indicates that in these patients nonalbumin protein calcium binding was more variable than that of albumin. A significant correlation

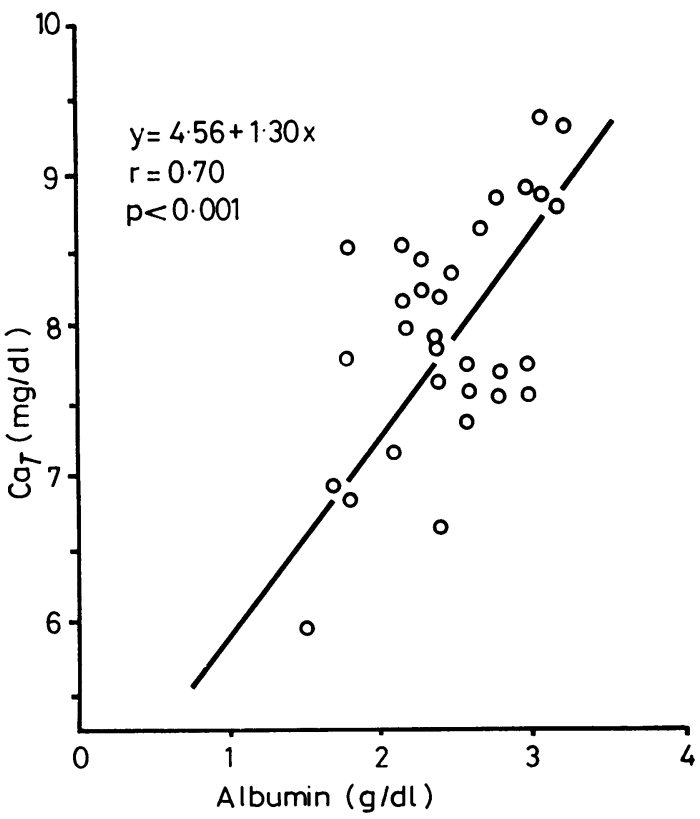

Fig. 1 Relation of total calcium to albumin in patients with hypoalbuminaemia.
( $r=0.76, p<0.001)$ was also noted between $\mathrm{Ca}_{T}$ and $\mathrm{Ca}_{\mathrm{uf}}$ as shown in Fig. 2. Neither total protein nor ultrafilterable fraction of calcium correlated with serum albumin concentration. We also plotted PTH (as measured by a carboxy-terminal assay against $\mathrm{Ca}_{u f}$; the results are shown in Fig. 3. Atr inverse relation between PTH concentrations an $\mathrm{Ca}_{u}$ is apparent. The two patients with severe rena insufficiency (plasma creatinine greater than $6 \mathrm{mg} / \mathrm{dl}$ )

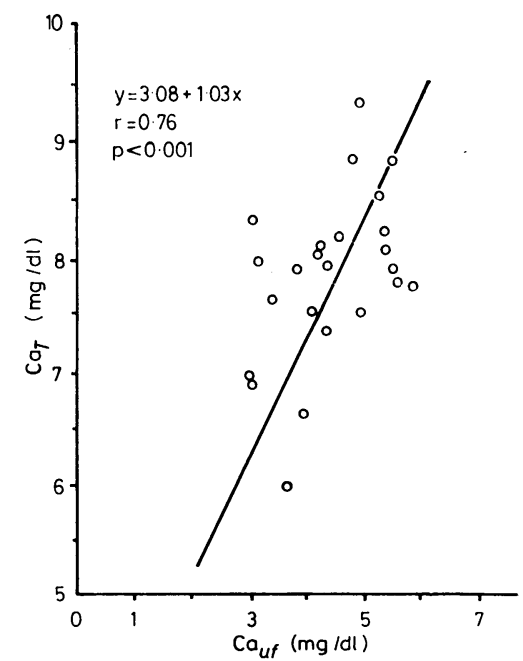

Fig. 2 Relation of total to ultrafilterable calcium in patients with hypoalbuminaemia. 
clearly have PTH concentrations disproportionately higher than the others. Since circulating PTH concentrations are primarily influenced by ionised calcium through a negative feedback system, the inverse correlation of PTH to $\mathrm{Ca}_{u}$ indicates that $\mathrm{Ca}_{u \text { u }}$ does reflect biologically active ionised calcium concentrations.

To ascertain whether calcium binding showed a similar inverse dependency on albumin concentration in vivo as noted by us previously in vitro, we plotted the amount of calcium bound per gram albumin against albumin (using the assumption previously stated). Results are depicted in Fig. 4. Although a large degree of scatter is present, the amount bound per gram of albumin decreased significantly with increasing albumin concentration $(r=0.60$, $\mathrm{p}<0.001$ ). We obtained a binding coefficient of less than $1 \mathrm{mg} \mathrm{Ca} / \mathrm{g}$ albumin only at albumin concentrations greater than $3 \mathrm{~g} / \mathrm{dl}$. The mean binding coefficient was $1.41 \mathrm{mg}$ calcium/g albumin but since some of the binding was not due to albumin and the curve shifted upwards by 10 to $25 \%$, the correct mean binding coefficient was approximately $1.16 \mathrm{mg}$ calcium/g albumin. The decrease in binding coefficient with albumin can only be accepted if non albumin proteins do not increase variably in response to different degrees of hypoalbuminaemia. The globulin concentrations were $3.03 \pm 0.64$ (SD), $3 \cdot 12 \pm 1 \cdot 19,2 \cdot 75 \pm 1 \cdot 17$, and $2 \cdot 88 \pm 0.38 \mathrm{~g} / \mathrm{dl}$ for

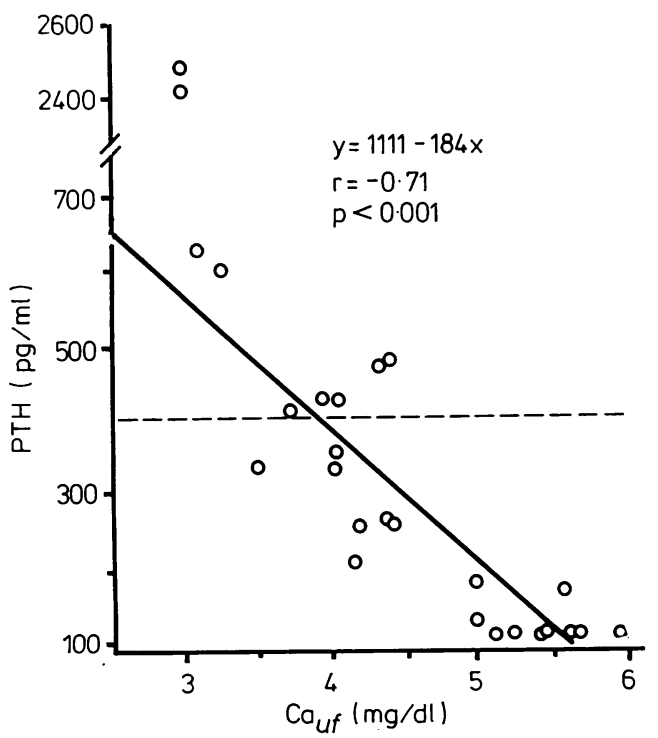

Fig. 3 In vivo relation of carboxyterminal plasma parathyroidhormone concentrations and ultrafilterable calcium; the two points above the break in the ordinate represent patients with renal failure. Horizontal line represents the normal upper limit.

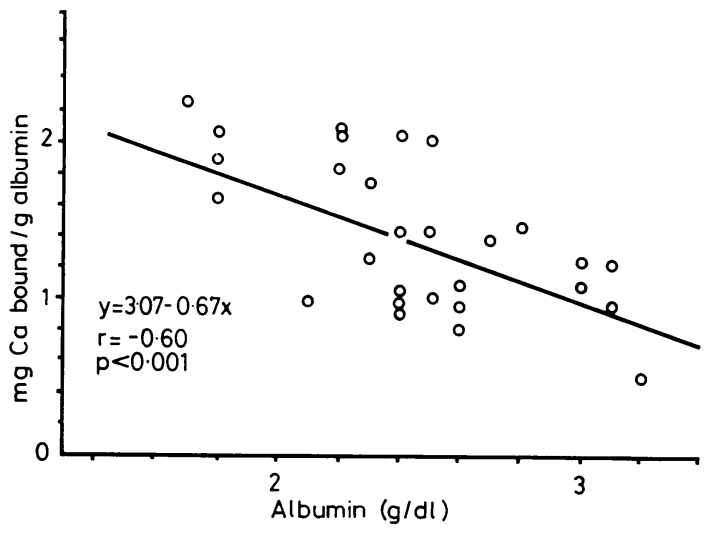

Fig. 4 Binding of calcium to albumin in hypoalbuminaemic states.

the four groups of patients with increasing albumin concentrations shown in Table 2 . This corresponded to an insignificant negative correlation of globulin to albumin concentration $(r=0 \cdot 164, p>0 \cdot 10)$. Apparently in this group of patients, globulin concentration was affected by their underlying diseases and not by oncotic factors related to hypoalbuminaemia.

The value of the correlation coefficient, $r=-0.60$, indicates that nearly $64 \%$ of the variance in the regression noted on Fig. 4 is not due to albumin concentration. This we believe is due to variation in ionised or ultrafilterable calcium. We noted that the decrease in binding constant with albumin in vitro was influenced by ultrafilterable calcium such that a series of parallel curves could be constructed at constant Caup. The limited amount of data in this clinical study precluded such an analysis for two reasons: first, a sufficient number of observations over a narrow range of $\mathrm{Ca}_{\mathrm{u}}$ could not be obtained; second, without measurement of $\mathrm{Ca}^{2+}$, the chelated calcium might vary considerably and produce artifacts.

In 10 patients in whom inoised calcium was measured (Table 3), it was below the lower normal limit of $4.6 \mathrm{mg} / \mathrm{dl}$ in seven. All three of the cancer patients, three of four nephrotic patients, and one of the cirrhotic patients had decreased $\mathrm{Ca}^{2+}$. $\mathrm{Had}$ a simple correction of 0.75 or $1.0 \mathrm{mg}$ calcium per gram albumin been used, total calcium and therefore ionised calcium would have been estimated to be within normal limits in eight of the 10 patients. The degree of ionic hypocalcaemia was most severe in the patients with cancer. In this group of 10 patients, the correlation of binding coefficient against albumin was also significant $(r=0.90, p<0.001)$ whereas no significant correlation of globulin to albumin 
Table 3 Ionic hypocalcaemia in some patients with hypoalbuminaemia

\begin{tabular}{|c|c|c|c|c|c|c|c|c|}
\hline $\begin{array}{l}\text { Disease } \\
\text { state }\end{array}$ & Patient & $\begin{array}{l}\text { Total } \\
\text { protein } \\
(\mathrm{g} / \mathrm{dl}) \\
(8 \cdot 2)\end{array}$ & $\begin{array}{l}A l b \\
(g / d l) \\
(3 \cdot 5)\end{array}$ & $\begin{array}{l}C a_{T} \\
(m g / d l) \\
(8 \cdot 5)\end{array}$ & $\begin{array}{l}C a_{u f} \\
(m g / d l) \\
(5 \cdot 0)\end{array}$ & $\begin{array}{l}C a^{2+} \\
(m g / d l) \\
(4 \cdot 6)\end{array}$ & $\begin{array}{l}\mathrm{Ca} / \mathrm{Ca} a_{T} \\
(\% \text { (helated }) \\
(9)\end{array}$ & $\begin{array}{l}\text { *'Corrected' } \\
\text { CaT } \\
(m g / d l)\end{array}$ \\
\hline Cancer & $\begin{array}{l}\text { JT } \\
\text { LM } \\
\text { JS }\end{array}$ & $\begin{array}{l}5 \cdot 6 \\
5 \cdot 4 \\
6 \cdot 3\end{array}$ & $\begin{array}{l}2 \cdot 8 \\
2 \cdot 1 \\
2 \cdot 4\end{array}$ & $\begin{array}{l}8 \cdot 2 \\
8 \cdot 0 \\
8 \cdot 5\end{array}$ & $\begin{array}{l}4 \cdot 0 \\
4 \cdot 1 \\
4 \cdot 6\end{array}$ & $\begin{array}{l}3 \cdot 1 \\
3 \cdot 2 \\
3 \cdot 3\end{array}$ & $\begin{array}{l}11 \\
11 \\
15\end{array}$ & $\begin{array}{l}9 \cdot 3 \\
9 \cdot 7 \\
9 \cdot 9\end{array}$ \\
\hline $\begin{array}{l}\text { Nephrotic } \\
\text { syndrome }\end{array}$ & $\begin{array}{l}\text { JR } \\
\text { JL } \\
\text { AM } \\
\text { LS }\end{array}$ & $\begin{array}{l}5 \cdot 0 \\
5 \cdot 1 \\
4 \cdot 8 \\
4 \cdot 9\end{array}$ & $\begin{array}{l}1 \cdot 4 \\
0 \cdot 8 \\
1 \cdot 3 \\
2 \cdot 6\end{array}$ & $\begin{array}{l}8 \cdot 2 \\
8 \cdot 6 \\
8 \cdot 4 \\
9 \cdot 1\end{array}$ & $\begin{array}{l}5 \cdot 6 \\
5 \cdot 8 \\
5 \cdot 2 \\
5 \cdot 5\end{array}$ & $\begin{array}{l}4 \cdot 3 \\
4 \cdot 6 \\
4 \cdot 1 \\
4 \cdot 5\end{array}$ & $\begin{array}{l}16 \\
14 \\
13 \\
11\end{array}$ & $\begin{array}{l}10 \cdot 5 \\
11 \cdot 4 \\
10 \cdot 8 \\
10 \cdot 3\end{array}$ \\
\hline $\begin{array}{l}\text { Liver } \\
\text { disease }\end{array}$ & $\begin{array}{l}\text { LM } \\
\text { KR } \\
\text { AS }\end{array}$ & $\begin{array}{l}5 \cdot 8 \\
6 \cdot 9 \\
6 \cdot 3\end{array}$ & $\begin{array}{l}2 \cdot 8 \\
3 \cdot 1 \\
2 \cdot 7\end{array}$ & $\begin{array}{l}9 \cdot 0 \\
8 \cdot 6 \\
8 \cdot 4\end{array}$ & $\begin{array}{l}5 \cdot 8 \\
6 \cdot 0 \\
5 \cdot 4\end{array}$ & $\begin{array}{l}4 \cdot 7 \\
5 \cdot 1 \\
4 \cdot 0\end{array}$ & $\begin{array}{l}12 \\
10 \\
17\end{array}$ & $\begin{array}{r}10 \cdot 1 \\
9 \cdot 4 \\
9 \cdot 5\end{array}$ \\
\hline
\end{tabular}

Values in parentheses are lower normal limits for each parameter.

*Calculated as Car corrected $=\mathrm{Ca}++0.88(4-\mathrm{Alb})$.

concentration was noted $(\mathrm{r}=0 \cdot 45, \mathrm{p}>0 \cdot 1)$. The increase in correlation coefficient in this smaller group compared to the previous larger group is probably due to the smaller range of $\mathrm{Ca}_{\mathrm{uf}}$ noted and the lower $(30 v 67 \%)$ frequency of lower $\mathrm{Ca}_{u f}$ values.

\section{Discussion}

The interaction of calcium with protein is of considerable physiological and practical importance. Many biological processes are known to be critically dependent on calcium ion activity. Changes in ionised serum calcium concentration, above or below normal levels, produce many clinical signs and symptoms. A variety of formulae have been developed to correct total serum calcium concentrations for changes in protein concentrations that may develop in different clinical states. None of these appears to be sufficiently precise to predict the ionised calcium in a given patient with accuracy unless the algorithm was developed for a specific group of patients. ${ }^{10}$ Many reasons account for this including the use of average regression coefficients which may not apply to a given patient, ${ }^{18}$ differences in the estimates of normalcy obtained from the various algorithms, ${ }^{19}$ and variable calcium binding to proteins other than albumin. ${ }^{17}$

A premise of many formulations is that the amount of calcium bound per gram albumin does not change with alterations in albumin concentration. The most commonly used factor for correcting total calcium for albumin concentration is that of Kleeman et $a l^{14}$ in which approximately 0.75 to $1.0 \mathrm{mg}$ calcium are bound to each gram of albumin. These values agree with those reported by Parfitt, ${ }^{9}$ Kelly et al $^{6}{ }^{6}$ and Orrell. ${ }^{8}$ By contrast Ljunghall ${ }^{7}$ obtained a value of 0.4 in a cohort of 2000 men whereas Pain et al $^{18}$ reported a range of values from 0.28 to $2 \cdot 1 \mathrm{mg} / \mathrm{gram}$ calcium bound per gram of albumin.

Our studies were stimulated by the sequential study of ultrafilterable calcium in a patient with multiple myeloma. Initially, she presented with hypercalcaemia, became hypocalcaemic during treatment with mithramycin and calcitonin, and finally became normocalcaemic after administration of intravenous and oral calcium supplements. Both total and protein bound calcium concentrations varied directly with $\mathrm{Ca}_{u \text { uf }}$ Neither serum albumin or immunoglobulins varied sufficiently to account for the changes in protein-bound calcium $(3.0$ to 8.5 $\mathrm{mg} / \mathrm{dl}$ ) observed during her clinical course. Thesg changes suggested that albumin was functioning as a source or sink for extracellular ionised calciure The results in this patient were consistent with oưr in vitro observations of a direct correlation between protein bound calcium and ultrafilterable calcium concentrations.

Our previous in vitro studies, however, suggested that the absolute albumin concentration was also an important determinant of the amount of calcium bound when ultrafilterable calcium was maintained constant. We chose to examine hypoalbuminaemic patients since in vivo data for such patients are sparse and our in vitro data suggested that protein binding of calcium in such patients might deviate the most from conventionally used values, thus leading to serious errors in estimating the biologically active calcium concentration. In our study we attempted to study a heterogeneous group of patients with differing disease processes to exclude effects specific to a particular disease entity or an effect due to treatment. We realise that in vivo many factors not present in vitro might influence calcium binding. These include variation in the concentration of other ions such as sodium, magnesium, and phosphate, ${ }^{20} 21$ the presence of chelators such as lactate and citrate, ${ }^{22}$ and alterations in fatty acids. ${ }^{23}$ Thus, quantitative comparison of in vivo with in vitro results could have been of limited value.

Despite these limitations, the agreement between 
our previous in vitro and these in vivo results was good. In both studies total calcium increases linearly with ultrafilterable calcium and with serum albumin concentrations. There was also excellent agreement of the in vivo data with published results of others. The regression coefficient of $\mathrm{Ca}_{\mathrm{T}}$ on total protein in vivo was $0 \cdot 48$, identical to the values obtained by Ladenson ${ }^{10}$ and Kelly et $a l^{6}$ both of whom studied much larger populations. The regression coefficient of $\mathrm{Ca}_{\mathrm{T}}$ on albumin, however, was 1.30 and greater than those obtained by others. The amount of calcium bound to albumin decreased from $1.97 \pm 0.2 \mathrm{mg} \mathrm{Ca} / \mathrm{g}$ albumin in patients with albumin concentrations less than $2 \mathrm{~g} / \mathrm{dl}$ to $1.08 \pm 0.32$ in patients with albumin concentrations greater than $3.0 \mathrm{~g} / \mathrm{dl}$. This inverse relation does not appear to be the result of changes in globulins. These results are consistent with those of Lim et al ${ }^{13}$ who studied a small group of patients with nephrotic syndrome. As serum albumin increased from $2.0 \pm 0.7$ during nephrosis to $3.7 \pm 0.4$ after remission, we calculated from their data a three-fold decrease in the regression of $\mathrm{Ca}_{T}$ on albumin concentration.

The importance of increased calcium binding during severe hypoalbuminaemia is that significant relative hypocalcaemia may exist but be unrecognised in such patients. In the absence of ionised calcium measurements, this was assessed by measurement of circulating PTH concentrations. The presence of an inverse relation between PTH concentrations and $\mathrm{Ca}_{u f}$ indicated that $\mathrm{Ca}_{\mathrm{uf}}$ did reflect biologically active calcium. The frequency of raised PTH concentrations (excluding those patients with renal insufficiency) decreased with increasing albumin concentrations (Table 2). Eight of 14 patients with serum albumin concentrations less than $2.4 \mathrm{~g} / \mathrm{dl}$ had raised PTH concentrations in contrast to only 1 of 14 patients with serum albumin concentrations greater than $2.5 \mathrm{~g} / \mathrm{dl}\left(\chi^{2}=5.89, \mathrm{p}<0.02\right)$. We compared the difference between estimated and measured ultrafilterable calcium concentration $\left(\mathrm{Ca}_{\text {uf }}\right)$ in 25 of these patients. Estimated ultrafilterable calcium was calculated as follows. Total calcium was corrected for albumin using the equation $\mathrm{Ca}_{\mathbf{T}}$ corr $=\mathrm{Ca}_{\mathrm{T}}+0.88 \Delta \mathrm{Alb}$ where $\Delta \mathrm{Alb}=4-\mathrm{Alb}$ and 0.88 is the mean of published regression coefficients for $\mathrm{Ca}_{T}$ on albumin. $\mathrm{Ca}_{\mathrm{T}}$ was then multiplied by 0.57 the fraction of total calcium which was ultrafilterable. The results are shown in Fig. 5. Only five values were negative-that is, ultrafilterable calcium was underestimated; 20 values were overestimated. The mean for the difference of underestimated values was $0.35 \mathrm{mg} / \mathrm{dl}$ and all patients in this group had PTH concentrations less than 105 (lower limit of detection). By contrast, the

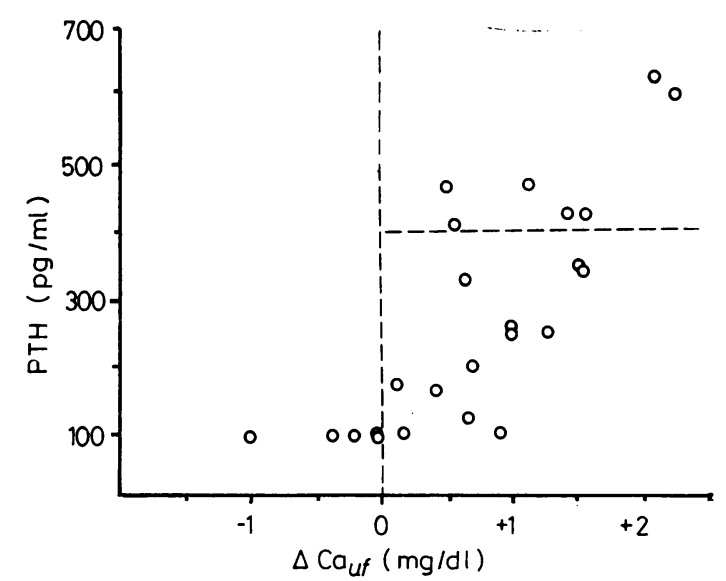

Fig. 5 Relation of carboxyterminal PTH concentrations to the difference between estimated $\mathrm{Ca} \mathrm{a}_{\mathrm{f}}$ (see text) and measured $\mathrm{Ca}$ uf.

mean for the difference of overestimated values was $0.95 \mathrm{mg} / \mathrm{dl}$ and in this group PTH values varied directly with the magnitude of $\Delta \mathrm{Ca}_{\text {uf }}$.

Measurement of ionised calcium in 10 additional hypoalbuminaemic patients confirmed the frequent occurrence of hypocalcaemia. Three of these had clinical signs of ionised hypocalcaemia but such would not have been suspected using the conventional correction factors (Table 3). Symptomatic hypocalcaemia was seen only in the cancer patients in this small group of patients. Chelated calcium was $11-15 \%$ of total and did not explain the decreased $\mathrm{Ca}^{2+}$.

There is too much variability in the clinical data to develop a useful nomogram to estimate $\mathrm{Ca}^{2+}$ or $\mathrm{Ca}_{u f}$ from a knowledge of plasma $\mathrm{Ca}_{\mathrm{T}}$ and $\mathrm{Alb}$ concentrations. Many variables affecting calcium protein binding were not examined or controlled and the binding may also be influenced by $\mathrm{Ca}^{2+}$ itself. Our data, however, do indicate that correction of total calcium by commonly used formulae may lead to overestimation of the true $\mathrm{Ca}^{2+}$ or $\mathrm{Ca}_{\text {up }}$ values and may mask significant ionic hypocalcaemia. Until future studies define the binding properties of human proteins more quantitatively as well as the important variables which affect such bindings, the patient with hypoalbuminaemia should be carefully assessed by measurements of ionic calcium and this correlated with clinical findings to detect those patients whose clinical symptoms may be manifestations of hypocalcaemia but attributed to their underlying disease. If ionic calcium cannot be measured, the effect of increased calcium binding at low albumin concentrations should be considered. An approxi- 
mation can be made using the relation $\mathrm{mg} \mathrm{Ca}$ bound $/ \mathrm{g}$ albumin $=0.77+0.50(3.5-\mathrm{Alb})$, that is the binding constant increases by approximately 0.50 for each gram of hypoalbuminaemia. Total bound calcium can then be obtained as the product of the binding constant and albumin concentration and when subtracted from measured $\mathrm{Ca}_{\mathrm{T}}$ give an estimate of $\mathrm{Ca}_{\text {uf. If }} \mathrm{Ca}_{\text {uf }}$ is less than $4.5 \mathrm{mg} / \mathrm{dl}$, the individual may have significantly depressed $\mathrm{Ca}^{2+}$.

This project was supported in part by NIAMD grant AM 19559. We thank Ms J Papaleo, C Gallagher, and $\mathrm{F}$ Hylan for secretarial assistance.

For a unit conversion table, please see preceding paper before references.

\section{References}

${ }^{1}$ McLean FC, Hastings AB. The state of calcium in the fluids of the body. I. The conditions affecting the ionisation of calcium. J Biol Chem 1935;108:285-322.

${ }^{2}$ Moore EW. Studies with ion exchange calcium electrodes. III. The state of serum calcium in patients with cirrhosis. Gastroenterology 1971;60:43-54.

${ }^{3}$ Payne RB, L. Ha AJ, Williams RB, Milner JR. Interpretation of serum calcium in patients with abnormal serum proteins. Br Med J 1973;4:643-6.

${ }^{4}$ Husdan H, Rapoport A, Locke S. Influence of posture on the serum concentration of calcium. Metabolism 1973; 22:787-90.

${ }^{5}$ Husdan R, Rapoport A, Locke S, Oreopaulos D. Effect of venous occlusion of the arm on the concentration of calcium in serum and methods for its compensation. Clin Chem 1974;20:529-32.

${ }^{6}$ Kelly AL, Munan C, Petitclerk C, Ho PK, Billon B. Use of values for calcium and protein in serum and of a derived index obtained from a probability population sample. Clin Chem 1976;22:1723-6.

${ }^{7}$ Ljunghall S, Hedstrand $\mathrm{H}$, Hellsing K, Wibell L. Calcium, phosphate and albumin in serum. Acta Med Scand 1977; $201: 23-30$.

${ }^{8}$ Orrell, DH. Albumin as an aid in the interpretation of serum calcium. Clin Chim Acta 1971;35:484-9.

${ }^{9}$ Parfitt AM. Correction of plasma calcium concentrations. Br Med J 1971;i:484-9.
${ }^{10}$ Ladenson JH, Lewis JW, Boyd JC. Failure of total calcium corrected for protein, albumin and $\mathrm{pH}$ to correctly $\overrightarrow{\overrightarrow{5}}$ assess free calcium status. J Clin Endocrinol 1978;46:으 986-93.

${ }^{11}$ Gosling P, Robinson BHP, Sammon S. Changes in protein bound calcium in the serum of hemodialysis patients. Clin Sci Mol Med 1975;48:521-8.

${ }^{12}$ Leme CE, Silva HS. Interactions of calcium ions with serum albumin in chronic renal failure. Clin Chim Acta 1977;77:287-99.

${ }^{13}$ Lim P, Jacob E, Chio LF, Pwee HS. Serum ionised calcium in nephrotic syndrome. Quart $J$ Med 1976. O $65: 421-6$.

${ }^{11}$ Kleeman CR, Massry SG, Colburn JW. The clinical physiology of calcium homeostasis, parathyroid hor- $\vec{\omega}$ mone and calcitonin. Calif Med 1971;114:16-43

${ }^{15}$ Besarab A, Caro J, DeGuzman A, Swanson JW. Effect of albumin and free calcium concentrations on calciumbinding in vitro. $J$ Clin Pathol 1981;34:1361-7

${ }^{16}$ Moore EW. Ionised calcium in normal serum, ultrafiltrates. and whole blood determined by ion exchange electrodes. $N$ J Clin Invest 1970;49:318-34.

${ }^{17}$ Toffaletti J, Savory J, Gitelman HJ. Use of gel filtration to examine the distribution of calcium among serum proteins. Clin Chem 1977;23:2306-10.

18 Pain RW, Rowland KM, Phillips PJ, McDuncan B Current "corrected" calcium concept challenged. $\mathrm{Br}$ Med J 1975; ; :617-9.

${ }^{19}$ Sanderson C. Correction of serum calcium concentrations. Br Med J 1974;i:245.

${ }^{20} \mathrm{Carr} \mathrm{CW}$. Competitive binding of calcium and magnesium with serum albumin. Proc Soc Exp Biol Med 1955;89: 546-9.

${ }^{21}$ Walser M, Robinson BH, Duckett JW Jr. The hyp calcemia of adrenal insufficiency. $J$ Clin Invest 196 $42: 456-65$.

${ }^{22}$ Greenberg DM, Larson CE. The relation of calcium proteinate and colloidal calcium phosphate to the partition of calcium in the blood stream. J Phys Chem 1939: 43:1139-50.

${ }^{23}$ Olthuis FMG, Kruisinga K, Soons JBJ. Interference of free fatty acids with the determination of calcium in sera. Clin Chim Acta 1973;49:123-4.

Requests for reprints to: Dr Anatole Besarab, M.D. Room 1014, College Building, Thomas Jefferson University, 1025 Walnut Street, Philadelphia, PA 19107, USA. 